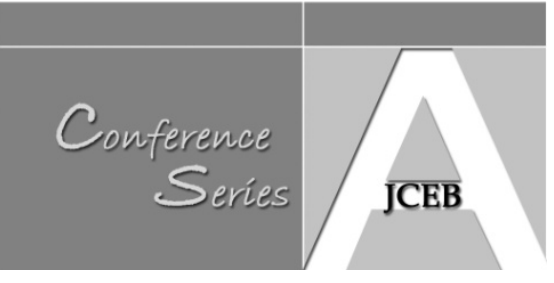

\title{
The Impacts of Housing Affordability on Social and Economic Sustainability in Beijing
}

Zhimin Wang, Jung Hoon Han and Benson Lim (The University of New South

Wales, Australia)

\begin{abstract}
China has undergone significant housing price growth since its 1998's policy reformation - triggering housing affordability issues in large cities such as Beijing and Shanghai. Although studies have been done to investigate Chinese cities' housing market policies, it appears that hitherto little is known about the effect of housing affordability on the cities' social and economic sustainability. The aim of this paper is to investigate the relationships among housing affordability, macro-economic performance and socio-demographic trends in Beijing. Under this aim, the specific objectives are to: examine Beijing's housing market performance, housing affordability, economic development and socio-demographic trends; and model the relationships among housing affordability, economic performance and socio-demographic trends in Beijing. Twelve years of retrospective census data from National Bureau of Statistics of China were collated and analysed. The results show that economic growth is positively influenced by housing affordability. However, it is shown that low level of housing affordability could lead to economic and social un-sustainability. This research informs urban planners and researchers about the effect of housing affordability on a nation's urban economic and social development, offering a new plausible insight towards developing a sustainable housing market.
\end{abstract}

Keywords: Economic performance, Housing affordability, Social environment, Sustainability

\section{Introduction}

Housing affordability is one of the major social and economic issues which have attracted the attentions of policy makers, urban researchers and planners in many countries. Over the past two decades, many countries have experienced a significant and persistent level of increase in housing prices (Kotkin 2011). This increase is often accompanied by changes in regional economic performance and labour market restructuring (Berry 2006), social cohesion and exclusion (Winter and Stone 1998; Coles et al. 2000), and social polarization(Winter and Stone 1998). Like other countries with the fast economic restructuring, China's housing affordability crisis is not exceptional.

Many studies have investigated the driving forces of housing affordability in China. For example, Li (2000) and Lau and Li (2006) suggested that the housing affordability problem was mainly driven by the housing supply and demand. Likewise, Li and Li (2006) and Song (2010) studied the relationships between households characteristics and their housing affordability, and found that life events such as marriage, childbirth were trigger factors of house demand. Also, some studies attributed the housing affordability problem to some inappropriate government policies, such as land policy (Du et al. 2011), "hukou" constraints (Wu 2002). However, little is known about the impact of housing affordability on China's economic performance and social stability.

The aim of this paper is to investigate the relationships among housing affordability, macro-economic performance and socio-demographic trends in Beijing. Under this aim, this 
paper will firstly examine Beijing's housing market performance, housing affordability, economic development and socio-demographic trends; and then model the relationships among housing affordability, economic performance and socio-demographic trends. Ascertaining the impact of housing affordability and house price on a city's economic and societal development is important because it will inform policy makers about significant development indicators, and in turn, help them to devise appropriate strategies towards achieving a more sustainable housing market.

\section{Literature Review}

The literature review revealed that China's housing market has significant influence on its economic and societal development. Their relationships are discussed below.

\section{Effect on economic development}

Many studies have demonstrated the impacts of house market on economic through the investment effect, and that increase in house price will attract investment, as a result of capital gain expectation, and hence economic development (Hongyu et al. 2002; Chen and Zhu 2008). Hongyu et al. (2002) found that the growth of housing investment in China contributed to GDP growth in the short run. Also, Peng et al. (2008) and Chen et al. (2011) found that property price inflation brought about real GDP growth in China mainly through the investment channel. However, Jin-hai (2009) have shown that overheated investment would result in unbalanced economics structure (Jin-hai 2009), and hence gave rise to instability of housing market, which will eventually affect the economic development (Clapham 1996; Beltratti and Morana 2010).

Also, studies have shown the influence of housing price on consumer expenditures. Matteo (2004) and Campbell and Cocco (2007) pointed out that the increase of house price simultaneously increases the value of wealth of home owners. The increase of housing wealth can promote household consumption, which also contributes to economic growth (Edelstein and Lum 2004). However, Peng et al. (2008) pointed out that there was a lack of wealth effect on consumption in China, mainly owing to the limited means to withdraw housing equity to finance current consumption. This is shared by Ouyang (2011) who pointed out that, due to the housing affordability crisis, many people in China reduce entertainment spend and careful calculation in daily expenditure in order to set aside money for down payment or mortgage payment. The decrease in consumer expenditure owing to the housing affordability will hold back the economic development.

\section{Effect on societal development}

Studies demonstrated the significant roles of homeownership on households life course decisions (Hughes 2003), such as household formation (Borsch-Supan 1986), child bearing and rearing (McLeod and Ellis 1982), and hence demographic trends (Borsch-Supan 1986), etc. Family life cycle and housing career theories hypothesized that life events are main determinants of housing demand (Doling 1976). However, the theory of planned behaviour indicated that households could adjust their life course according to their housing affordability (Icek 1991). For example, Ermisch and Salvo (1997) and Di and Liu (2006) found that housing market circumstances and house cost are important variables towards explaining the probability of independent living. Haurin et al. (1995) found that marriage rate is negatively correlated with house price. This is further established by Ouyang (2011), who

Wang, Z., Han, J.H. and Lim, B. (2012) 'The impacts of housing affordability on social and economic sustainability in Beijing', Australasian Journal of Construction Economics and Building, Conference Series, 12 (1) 47-55 
found that many young people in China delay their marriage and childbirth owing to the housing affordability crisis. Therefore, housing market situation could have impact on the regional demographic changes, such as household formation, age group structure and household size structure. The demographic structure and trend are important features of social sustainability (Copus and Crabtree 1996; Singh et al. 2012).

\section{Data Analysis}

The data of this paper is mainly from Chinese government statistics reports such as Beijing Statistic Yearbook and China Economic Information Network Database (CEIND). Time series data over the period of 1999 to 2011 were analysed by using descriptive analysis, chisquare test and regression modelling technique.

The measurement of housing affordability used in this paper is Median house price to Median household income1. Two independent latent variables are used: economic sustainability and social sustainability. The definition of economic sustainability is “continuous and indefinitely (or at least long-term) sustained growth" (Spangenberg 2005). And social sustainability is defined as "stable human populations" (Brown et al. 1987) and "the ability of the population to reproduce itself" (Copus and Crabtree 1996). The measurement items of these two latent variables are shown in Table 1.

Table 1. Measurement of economic and social sustainability

\begin{tabular}{|c|c|c|}
\hline Dimension & Indicator & Measurement \\
\hline \multirow[t]{4}{*}{$\begin{array}{l}\text { Economic } \\
\text { sustainability }\end{array}$} & $\begin{array}{l}\text { Economic development } \\
\text { (GRI 2002) }\end{array}$ & $\begin{array}{l}\text { Gross Domestic Product (GDP) } \\
\text { (Copus and Crabtree 1996) }\end{array}$ \\
\hline & $\begin{array}{l}\text { Economic structure } \\
\text { (UNCSD 2001) }\end{array}$ & $\begin{array}{l}\text { Housing investment (HI) } \\
\text { (IChemE 2002) }\end{array}$ \\
\hline & $\begin{array}{l}\text { Consumption patterns } \\
\text { (UNCSD 2001) }\end{array}$ & $\begin{array}{l}\text { Household consumption (HC) } \\
\text { (Campbell and Cocco 2007) }\end{array}$ \\
\hline & $\begin{array}{l}\text { Inflation } \\
\text { (GRI 2002) }\end{array}$ & $\begin{array}{l}\text { Consumer Price Index (CPI) } \\
\text { (Follain 1982) }\end{array}$ \\
\hline \multirow[t]{2}{*}{$\begin{array}{l}\text { Social } \\
\text { sustainability }\end{array}$} & $\begin{array}{l}\text { Demographic structure } \\
\text { (UNCSD 2001) }\end{array}$ & $\begin{array}{l}\text { Labour force (LF), household size (HS) } \\
\text { (Copus and Crabtree 1996) }\end{array}$ \\
\hline & $\begin{array}{l}\text { Household formation } \\
\text { (Borsch-Supan 1986) }\end{array}$ & $\begin{array}{l}\text { Marriage rate (MR), birth rate (BR) } \\
\text { (Copus and Crabtree 1996) }\end{array}$ \\
\hline
\end{tabular}

\section{House price and housing affordability in Beijing}

The housing market in China established in 1998 marked with the market-oriented reform of its housing system. In the early 2000s, Chinese government established several policies to stimulate housing market development, such as increasing land release, loose monetary policies, and public housing subsidies. Figure 1 shows the house price in Beijing was stable at around RMB 5000 (RMB1 = A \$0.15 as of 24/02/2012) before 2005. This could partially be explained in relation to the implementation of favourable housing policies, which relieved the stress of housing affordability. Figure $1 \mathrm{~b}$ shows the median house price to median income ratio dropped from 25 in 1999 to 12 in 2004.

\footnotetext{
${ }^{1}$ Median house price/Median household income=(average house price *100 square meters)/(average monthly household income*12)

Wang, Z., Han, J.H. and Lim, B. (2012) 'The impacts of housing affordability on social and economic sustainability in Beijing', Australasian Journal of Construction Economics and Building, Conference Series, 12 (1) 47-55
} 


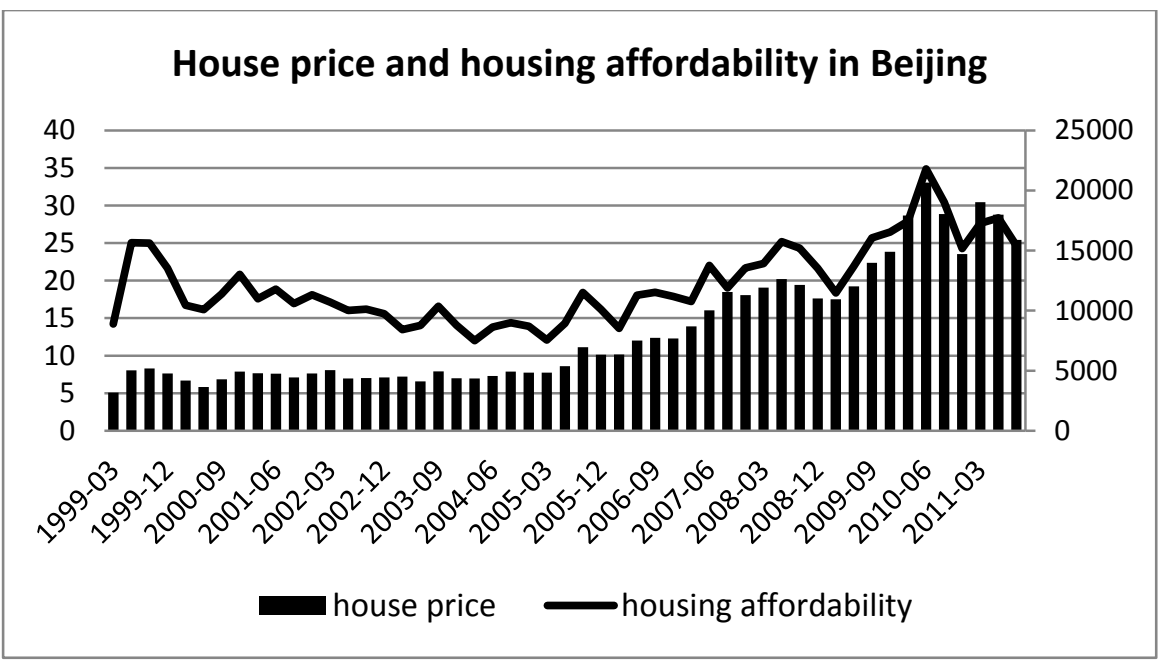

Figure 1. House price and housing affordability in Beijing

(Data source: China Economic Information Network)

However, the house price grows dramatically since 2005. The global financial crisis in 2008 caused slight decline in house price. Various stimulus policies were implemented by the government from 2008 to 2009 to cushion the financial crisis impacts. These include: increase investing affordable housing, loosening monetary policies and other favourable policies. A sign of recovery for the industry was reflected in 2010 where the house price growth rebounded - indeed, it further worsens the house affordability situation in Beijing. Figure 1b shows that the median house price to median household income ratio in Beijing had increased dramatically from 12 in 2004 to 35 in 2010.

\section{Economic performance in Beijing}

The rapid growth of economy in Beijing is mainly owing to the expansion of the real estate industry. Figure 2a shows the city's GDP has grown at a constant rate of $10 \%$ to $14 \%$ yearly, with an exception of 2008 at 9\% owing to the global financial crisis. The real estate investment contributes considerably to the city's GDP every year, with the highest point in 2004 at 25\%. However, the percentage of residents' consumption in GDP declined from 40\% in 1999 to $30 \%$ in 2007.

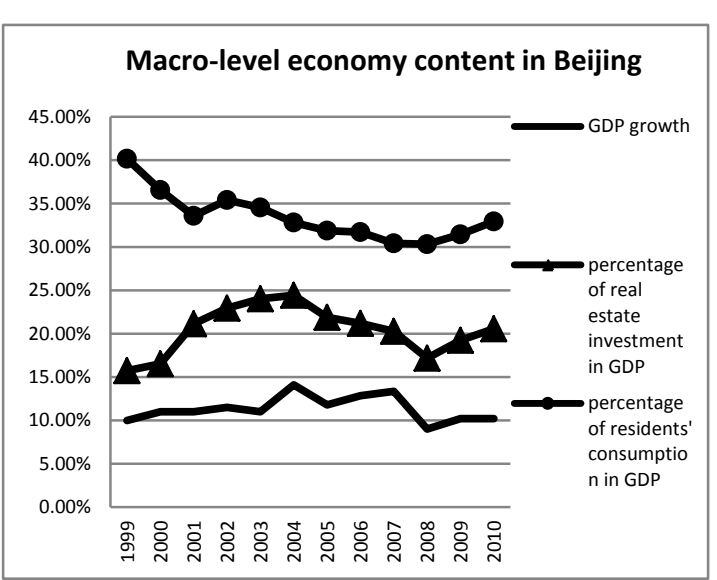

Figure 2a. Macro-level economy content in Beijing

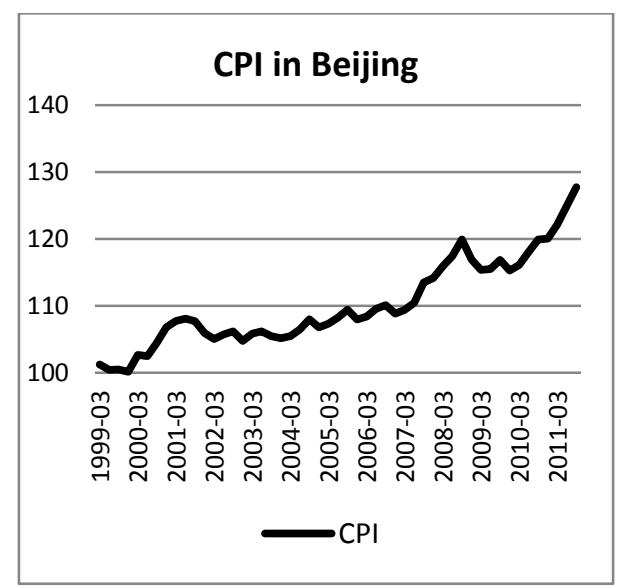

Figure 2b. Inflation in Beijing

(Data source: China Economic Information Network and Beijing Statistic Yearbook (2000-2011))

Wang, Z., Han, J.H. and Lim, B. (2012) 'The impacts of housing affordability on social and economic sustainability in Beijing', Australasian Journal of Construction Economics and Building, Conference Series, 12 (1) 47-55 
Figure 2b indicates that the Consumer Price Index (CPI) in Beijing have subject to three periods of inflation at 2000, 2008, and 2011. The inflation brings more stress on the residents in Beijing for daily life expenditures.

\section{Social and demographic changes in Beijing}

According to Beijing Statistic Bureau (BSB 2011), the total population in Beijing increased from 12.46 million in 1998 to 19.61 million in 2010, with an average yearly increase rate of 4.4\%. Figure 3a shows that the percentage of labour force (population aged from 15 to 64) accounted for more than $66 \%$ over the 12 years, and that there is an increase in labour force during 2009 - 2010. It is reported that young people immigrated from other provinces to Beijing for work or study contributed to these population increases in Beijing (Census 2011). The features of demographic could partially explain the increase of marriage rate and birth rate since 2006. However, it is found that the household size has decreased over the last decade, as shown in figure $3 \mathrm{~b}$ shows that.

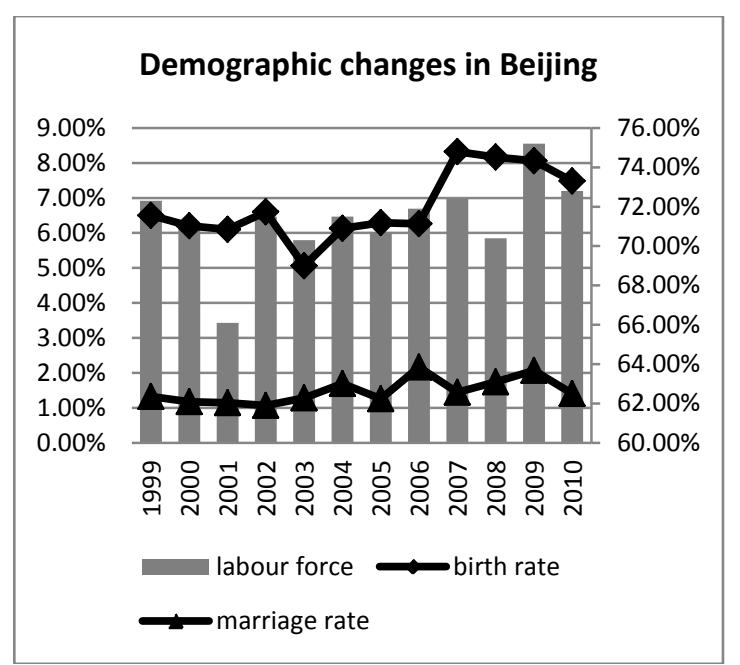

Figure 3a. Demographic changes in Beijing

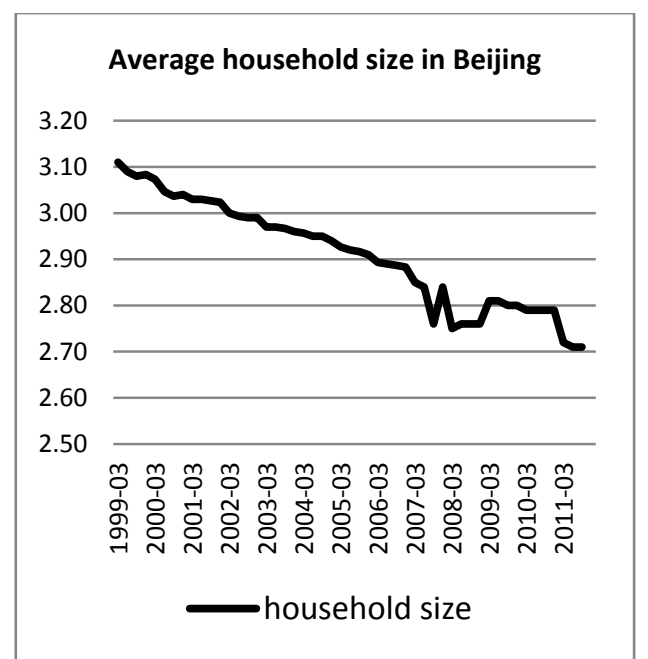

Figure 3b. Household structure in Beijing

(Data source: Beijing statistic yearbook (2000-2011) and China Economic Information Network)

\section{Statistical analysis}

Table 2 summarises the curve regression results on Beijing's housing affordability, and its economic performance and household size changes. It is surprise to find that GDP is positively related with housing affordability, which indicates that lower level of housing affordability promotes economic growth. This unconventional phenomenon could partially be explained by the cosine cubic curvature relationships between housing investment, household consumption and housing affordability: (1) the low housing affordability aggravates local households' housing expenditure; and (2), high house price attracts more investment in the housing industry. However, the cosine cubic curvature results of GDP growth rate and CPI also show that the worsening housing affordability have caused high inflation and decline in GDP growth rate in Beijing. 
Table 2. Estimate results for the impact of housing affordability on economic and household size changes

\begin{tabular}{lllllll}
\hline \multirow{2}{*}{$\begin{array}{l}\text { Depende } \\
\text { nt }\end{array}$} & Equation & \multicolumn{3}{c}{ Model summary } & \multicolumn{3}{l}{ Standardized coefficients } \\
\cline { 3 - 6 } variable & & R Square & Sig. & HA & HA*2 & HA*3 $^{*}$ \\
\hline GDP & S & 0.660 & .000 & $-0.813^{2} * *$ & & \\
GDPGR & Cubic & 0.587 & .000 & -5.468 & 14.036 & -8.001 \\
HI & Cubic & 0.298 & .001 & -4.516 & 9.669 & -4.717 \\
HC & Cubic & 0.381 & .000 & -6.466 & 13.454 & -6.530 \\
CPI & Cubic & 0.471 & .000 & -5.480 & 12.313 & -6.295 \\
HS & Cubic & 0.350 & .000 & 6.204 & -13.457 & 6.828 \\
\hline
\end{tabular}

**indicates $\mathrm{P}<0.01$

For the demographic changes, table 2 shows that household size is sine curvature cubic related to housing affordability. The chi-square test results in table 3 show that none of marriage rate, birth rate and labour force is significantly influenced by the changes of housing affordability in Beijing. These results could partially be explained by Census (2011) indicated that young people (aged from 20 to 39) immigrated from other provinces to Beijing for work or study contributed to the population increases in Beijing. Apart from joining the labour force, these young immigrations are entering their marriage and child birth age. Therefore, the immigrants contribute to the sustainable social and demographic trends in Beijing.

Table 3. Chi-Square of cross table analysis of housing affordability influences on demographic structures

\begin{tabular}{lll}
\hline variables & \multicolumn{2}{l}{ Pearson Chi-Square } \\
\cline { 2 - 3 } & Value & $\begin{array}{l}\text { Asymp.Sig (2- } \\
\text { sided) }\end{array}$ \\
\hline Labour force & 9.200 & 0.056 \\
Birth rate & 9.200 & 0.056 \\
Marriage rate & 5.203 & 0.267 \\
\hline
\end{tabular}

\section{Conclusion}

This study investigated the influence of Beijing's housing affordability on its social and economic sustainable development. It is concluded that there is a likely relationship between housing affordability and economic development. Housing affordability could promote economic development by attracting housing investment and stimulating housing consumption. However, low level of housing affordability has negative impact on other economic performance indicators, such as overheated housing investment, unbalanced economic structure, inflation, and declining GDP growth rate. These negative effects could hinder the achievement of economic sustainability.

Second, there is no sufficient evidence indicating the impact of housing affordability on Beijing's demographic changes. Possible explanation of this result is that young migrants from other province contribute to the sustainable demographic change in Beijing. However, Beijing may lose its attraction to migrants if its house price keeps growing and housing

\footnotetext{
${ }^{2}$ The independent variable in this equation is 1 /housing affordability.

Wang, Z., Han, J.H. and Lim, B. (2012) 'The impacts of housing affordability on social and economic sustainability in Beijing', Australasian Journal of Construction Economics and Building, Conference Series, 12 (1) 47-55
} 
affordability worsening, which would cause unsustainable demographic and population growth.

Lastly, it is acknowledged that, owing to the exploratory nature of this study and its small sample size and limited indicators used, the results are not definitive but indicative of a perceived trend. Therefore, further and detailed investigation should be conducted for the generalization of findings by including other social and economic sustainability measures.

\section{References}

Beltratti, A. and Morana, C. (2010). 'International house prices and macroeconomic fluctuations.' Journal of Banking \& Finance, 34, 533-545.

Berry, M. (2006). 'Housing affordability and the economy: A review of labour market impacts and policy issues'. Australian Housing and Urban Research Institute Publication Series, retrieved from http://www.ahuri.edu.au/downloads/NRV3/NRV3_Research_Paper_5.pdf, $\quad$ viewed: $<$ November 23 2011>.

Borsch-supan, A. (1986). 'Household formation, housing prices, and public policy impacts.' Journal of Public Economics, 30, 145-164.

Brown, B.J., Hanson, M. E., Liverman, D.M. and Merideth, R.W. (1987). 'Global sustainability: Toward definition.' Environmental Management, 11, 713-719.

BSB. (2011). 'Beijing Statistic Yearbook', Beijing Statistical Information Net, retrieved from http://www.bjstats.gov.cn/nj/main/2011-tjnj/index.htm, <March 15 2012>.

Campbell, J. and Cocco, J. (2007). 'How do house prices affect consumption? Evidence from micro data.' Journal of Monetary Economics, 54, 591-621.

Census. 2011. 'The features of population changes in Beijing', The Sixth National Population Census, Beijing, retrieved from http://www.bjstats.gov.cn/rkpc_6/pcsj/201105/t20110530_203325.htm, < May 30 2012>.

Chen, J., Guo, F. and Zhu, A. (2011). 'The Housing-led Growth Hypothesis Revisited: Evidence from the Chinese Provincial Panel Data.' Urban Studies, 48, 2049-2067.

Chen, J. and Zhu, A. (2008). 'The relationship between housing investment and economic growth in China: a panel analysis using quarterly provincial data', Uppsala University Publication Series, retrieved from http://www.nek.uu.se, < January 11 2012>.

Clapham, D. (1996). 'Housing and the Economy: Broadening Comparative Housing Research.'Urban Studies, 33, 631-647.

Coles, B., England, J. and Rugg, J. (2000). 'Spaced Out? Young People on Social Housing Estates: Social Exclusion and Multi-agency Work.' Journal of Youth Studies, 3, 21-33.

Copus, A.K. and Crabtree, J.R. (1996). 'Indicators of socio-economic sustainability: An application to remote rural Scotland.' Journal of Rural Studies, 12, 41-54.

Di, Z. X. and Liu, X. (2006). 'The effects of housing push factors and rent expctations on household formation of young adults.' Journal of Real Estate Research, 28, 149-166.

Doling, J. (1976). 'The family life cycle and housing choice'. Urban Studies, 13, 55-58.

Wang, Z., Han, J.H. and Lim, B. (2012) 'The impacts of housing affordability on social and economic sustainability in Beijing', Australasian Journal of Construction Economics and Building, Conference Series, 12 (1) 47-55 
Du, H., Ma, Y. and An, Y. (2011). 'The impact of land policy on the relation between housing and land prices: Evidence from China.' The Quarterly Review of Economics and Finance, 51, 19-27.

Edelstein, R.H. and Lum, S.K. (2004). 'House prices, wealth effects, and the Singapore macroeconomy.' Journal of Housing Economics, 13, 342-367.

Ermisch, J. and Salvo, P.D. (1997). 'The Economic Determinants of Young People's Household Formation.' Ecomonica, 64, 627-644.

Follain, J.R. (1982). 'Does Inflation Affect Real Behavior: The Case of Housing'. Southern Economic Journal, 48, 570-582.

GRI, (2002). Sustainability reporting guidelines, Grobal Reporting Initiative, Boston.

Haurin, D.R., Wachter, S.M. and Hendershott, P.H. (1995). 'Wealth accumulation and housing choices of young households an exploratory investigation'. NBER Working Paper Series, retrieved from:http://www.nber.org/papers/w5070.pdf?new_window=1, <January 08 2012>.

Hongyu, L., Park, Y.W. and Siqi, Z. (2002). 'The Interaction between Housing Investment and economic growth in China.'International Real Estate Review, 5, 40-60.

Hughes, M. E. (2003). 'Home economics: metropolitan labor and housing markets and domestic arrangements in young adulthood.' Social Forces, 81, 1399-1429.

Icek, A. (1991). 'The theory of planned behavior.' Organizational Behavior and Human Decision Processes, 50, 179-211.

IChemE. (2002). 'The sustainability metrics: sustainable development progress metrics recommended for use in the process industires'. Institution of Chemical Engineers, retrieved from: http://nbis.org/nbisresources/metrics/triple_bottom_line_indicators_process_industries.pd f, <February 02 2012>.

Jin-hai, Y. (2009). 'Study on impact of housing price on output and inflation rate in China.' China Land Science, 23, 14-19.

Kotkin, J. (2011). '7th Annual Demographia International Housing Affordability Survey: 2011', Demographia Publication Series, retrieved from: http://heartland.org/sites/all/modules/custom/heartland_migration/files/pdfs/29948.pdf, $<$ January 02 2012>.

Lau, K. and Li, S. (2006). 'Commercial housing affordability in Beijing, 1992-2002.' Habitat International, 30, 614-627.

Li, S.-M. (2000). 'The Housing Market and Tenure Decisions in Chinese Cities: A Multivariate Analysis of the Case of Guangzhou.' Housing Studies, 15, 213-236.

Li, S.-M. and Li, L. (2006). 'Life Course and Housing Tenure Change in Urban China: A Study of Guangzhou.' Housing Studies, 21, 653-670.

Matteo, I. (2004). 'Consumption, house prices, and collateral constraints: a structural econometric analysis.' Journal of Housing Economics, 13, 304-320.

Mcleod, P. B. and Ellis, J. R. (1982). 'Housing Consumption Over the Family Life Cycle: an Empirical Analysis.' Urban Studies, 19, 177-185. 
Ouyang, H. (2011). 'Living condition investigation of young people in large and mediumsized cities in China'. Xiaokang Index Qiushi Journal, retrieved from: http://xkzz.chinaxiaokang.com/xkzz3/newsview.asp?id=5485, < May 31 2011>.

Peng, W., Tam, D. C. and Yiu, M. S. (2008). 'Property market and the macroeconomy of mainland China: a cross region study.' Pacific Economic Review, 13, 240-258.

Singh, R. K., Murty, H. R., Gupta, S. K. and Dikshit, A. K. (2012). 'An overview of sustainability assessment methodologies.' Ecological Indicators, 15, 281-299.

Song, J. (2010). 'Moving Purchase and Sitting Purchase: Housing Reform and Transition to Homeownership in Beijing.' Housing Studies, 25, 903-919.

Spangenberg, J. H. (2005). 'Economic sustainability of the economy: concepts and indicators.' International journal of sustainable development, 1, 47-64.

UNCSD, (2001). The United Nations Commission for Sustainable Development theme indicator framework, Department of Economic and Social Affairs, New York.

Winter, I. and Stone, W. (1998). 'Social polarisation and housing careers: exploring the interrelationship of labour and housing markets in Australia', Australia Institute of Family Studies Series, retrieved from: http://www.aifs.gov.au/institute/pubs/WP13.pdf, < February 24 2012>.

Wu, W. (2002). 'Migrant Housing in Urban China: Choices and Constraints.' Urban Affairs Review, 38, 90-119. 